\title{
Herpetofauna of protected areas in the Caatinga II: Serra da Capivara National Park, Piauí, Brazil
}

\author{
Lucas Barbosa de Queiroga Cavalcanti ${ }^{1 *}$, Taís Borges $\operatorname{Costa}^{1}$, Guarino Rinaldi Colli ${ }^{2}$, Gabriel Corrêa \\ Costa $^{3}$, Frederico Gustavo Rodrigues França ${ }^{4}$, Daniel Oliveira Mesquita ${ }^{1}$, Cristiane Nikely Silva \\ Palmeira ${ }^{5}$, Nicolás Pelegrin ${ }^{6}$, Ana Hermínia Bello Soares ${ }^{2}$, Derek B. Tucker ${ }^{7}$ and Adrian Antonio \\ Garda $^{3}$
}

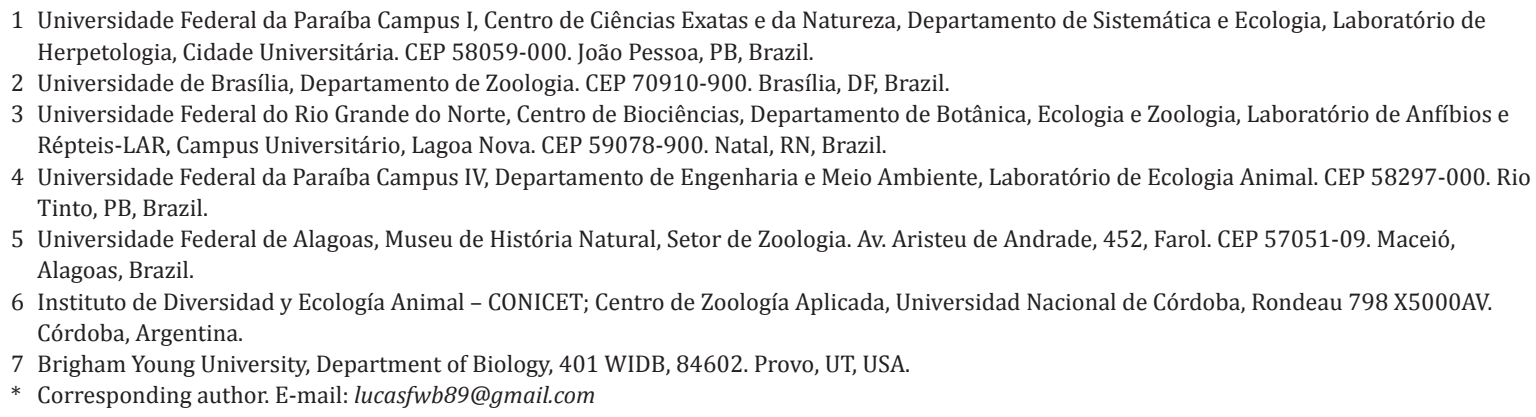

\begin{abstract}
We provide a list of amphibians, lizards, chelonians, and snakes collected during a 30-day expedition to the Serra da Capivara National Park, Piauí State, Brazil. Thirty-seven pitfall trap arrays composed of 4 buckets each, along with glue traps, funnel traps, and haphazard searches, were used to sample the herpetofaunal diversity. We recorded 17 species of lizards, 1 caecilian, 1 chelonian, 7 frogs, and 11 snakes. Rarefaction curves suggest that local biodiversity is still underestimated. An atypical drought during the period of study may have contributed to lower captures of certain groups, especially amphibians and snakes. The presence of water-dependent and forest-dependent species within local canyons ("Boqueirões") suggests that these areas harbor faunas associated with relictual rainforest fragments and need to be better studied and managed accordingly.
\end{abstract}

\section{INTRODUCTION}

The Caatinga morphoclimatic domain, an exclusively Brazilian biome, is a semi-arid region covering more than $800,000 \mathrm{~km}^{2}$ in northeastern South America. As with most semi-arid regions, solar radiation and mean annual temperatures are high, air humidity is low, and average rainfall is low and irregularly distributed throughout the year (Prado 2003). There are many soil types, from sandy to clayey, with rocky outcrops that vary in size and abundance throughout the biome distribution. The Caatinga has a broad range of floristic formations, such as forests composed of medium to large sized trees with canopy formation, a fundamental characteristic to classify the Caatinga as a Seasonally Dry Tropical Forest (Sensu Werneck 2011). Other regions, in contrast, are covered almost exclusively by shrubs, herbaceous plants, cactus, and sparse small trees (Leal et al. 2003).

Thirteen strictly protected federal areas encompass $9920 \mathrm{~km}^{2}$ (roughly 1\% of the Biome's area): Castanhão, Seridó, Raso da Catarina, and Aiuaba Ecological Stations; Furna Feia, Serra Negra, Serra da Capivara, Serra das Confusões, Chapada Diamantina, Catimbau, Ubajara and Sete Cidades National Parks; and Rio São Francisco Natural Monument. Most of these protected areas suffer from structural deficiencies, lack of well conducted biological inventories, and problems with their implementation process (Leal et al. 2005).
Despite the recent recognition that the Caatinga harbors several herpetofaunal endemics and one of the highest diversities for any biome under its climatic conditions (Rodrigues 2003), most of the region is still inadequately sampled (Tabarelli and Vicente 2004). This is reflected in the paucity of data on reptiles and amphibians for the few federally protected areas that exist in this morphoclimatic domain.

As one of the goals of the Project "Representatividade da Herpetofauna em Unidades de Conservação da Caatinga: Diversidade, filogeografia e Relações com Biomas não Florestais da América do Sul" (CNPq/ICMBIO), we present herein the results of a 30-day field expedition to Parque Nacional Serra da Capivara, the second of nine field trips to be conducted in strictly protected areas in the Caatinga.

\section{Materials ANd Methods}

Serra da Capivara National Park (PARNA Serra da Capivara) is a 91,848.88 ha protected area in Piauí State, Brazil (Figure 1). Its perimeter totals more than $200 \mathrm{~km}$ and crosses four municipalities: São Raimundo Nonato, Coronel José Dias, Brejo do Piauí, and João Costa. A dense arboreal Caatinga (Caatinga arbórea densa) with some arbustive elements over a compact sandy soil (Figure 2) characterizes most of the park, while bushes and several cacti and bromeliads cover rocky outcrops (Lemos 2004). The edge of the highland areas (Chapadas) has steep cliffs 
and forms deep, long canyons commonly known to local people as "Boqueirões". The vegetation in these canyons is composed of semi-deciduous, mesic forests with tall canopy cover (Figure 3). Inside the park there are no natural water bodies, but a system of artificial water channels and ponds is used to provide water to animals by the park administration.

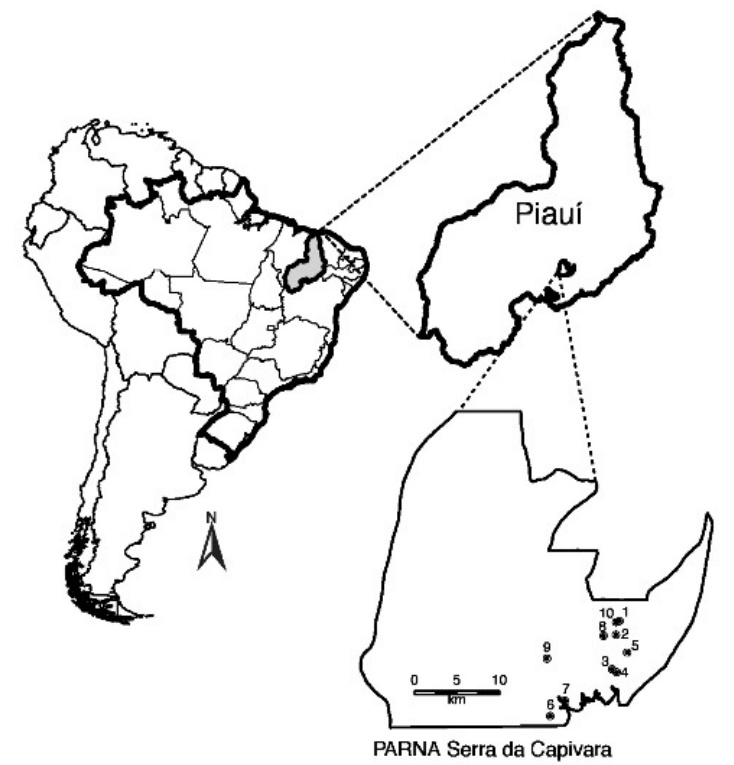

FIGURE 1. Schematic map showing study site location and the ten sampled points. Points 1 and 2 refer to the pitfall trap arrays trails, while points $3-10$ were sampled by haphazard searches.

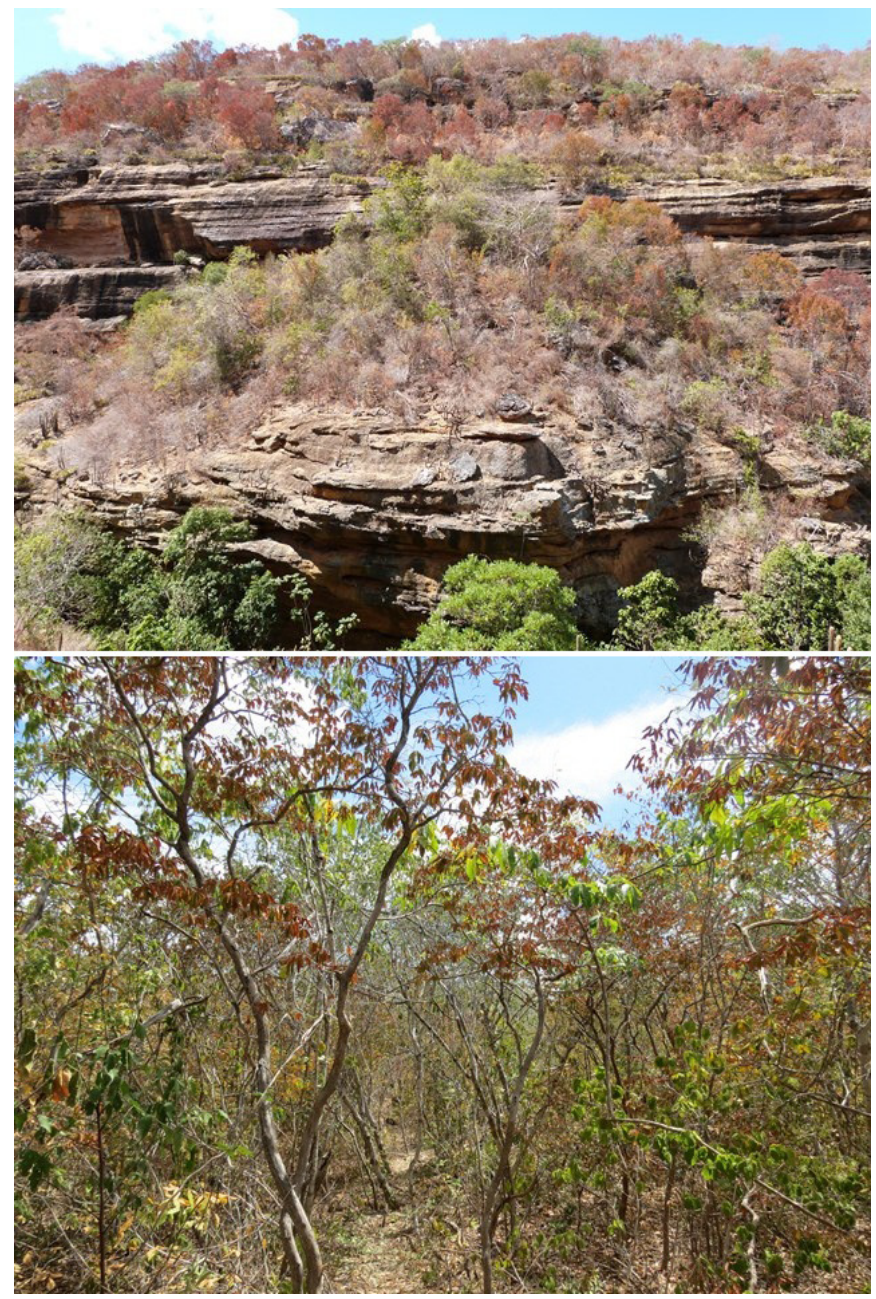

FIGURE 2. Typical arboreal and arbustive Caatinga vegetation in PARNA Serra da Capivara - PI.

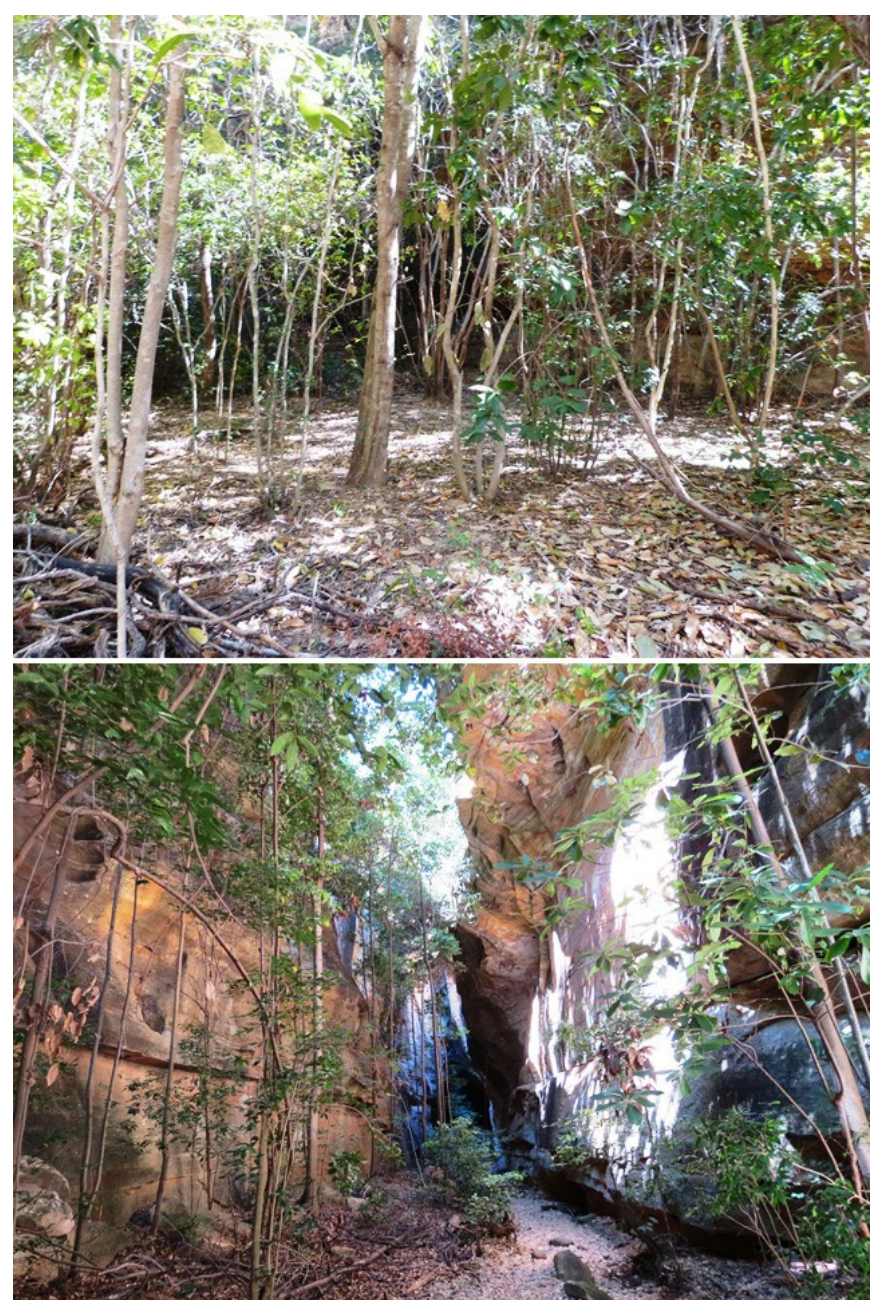

FIGURE 3. "Boqueirão" forest enclaves between cliffs in PARNA Serra da Capivara- PI.

We sampled squamates, turtles, and amphibians from May 6th to June 6th, 2012 using active random searches by four experienced collectors for at least 8 hours per day across ten different sampling points, and two lines of pitfall trap arrays (Figure 1). We installed 37 pitfall trap arrays composed of four $30 \mathrm{~L}$ buckets each disposed in a Y shape, with one central bucket and three on the extremities, connected by three $6 \mathrm{~m}$ drift fences built with plastic sheets (Figure 4) (Corn 1994; Cechin and Martins 2000). We placed the trap arrays in a straight line, 20 $\mathrm{m}$ apart. At each drift fence, we placed two funnel traps (one on each side of the fence), totaling 6 funnel traps per array. We also placed four glue traps on each trap array, on several microhabitats (two on the ground and two on the vegetation, and across fallen branches). Traps were placed in two trails in separated regions of the Park, with 18 and 19 arrays each (Figure 1, points 1-2).

Total sampling effort was 30 days, 26640 hours of trap arrays and 960 hours of active rand om searches. Specimens were killed with lidocaine (applied to the abdomen of amphibians or injected into reptiles), fixed in a solution of $10 \%$ formalin and preserved in a $70 \%$ ethanol solution. Specimens were collected according to permits granted by appropriate agencies to AAG (SISBIO \# 33402-1) and TBC (SISBIO \# 29550-2). All specimens are deposited at Coleção Herpetológica da Universidade Federal da Paraíba (CHUFPB) and Coleção Herpetológica do Laboratório de Anfíbios e Répteis da UFRN (CLAR-UFRN). 


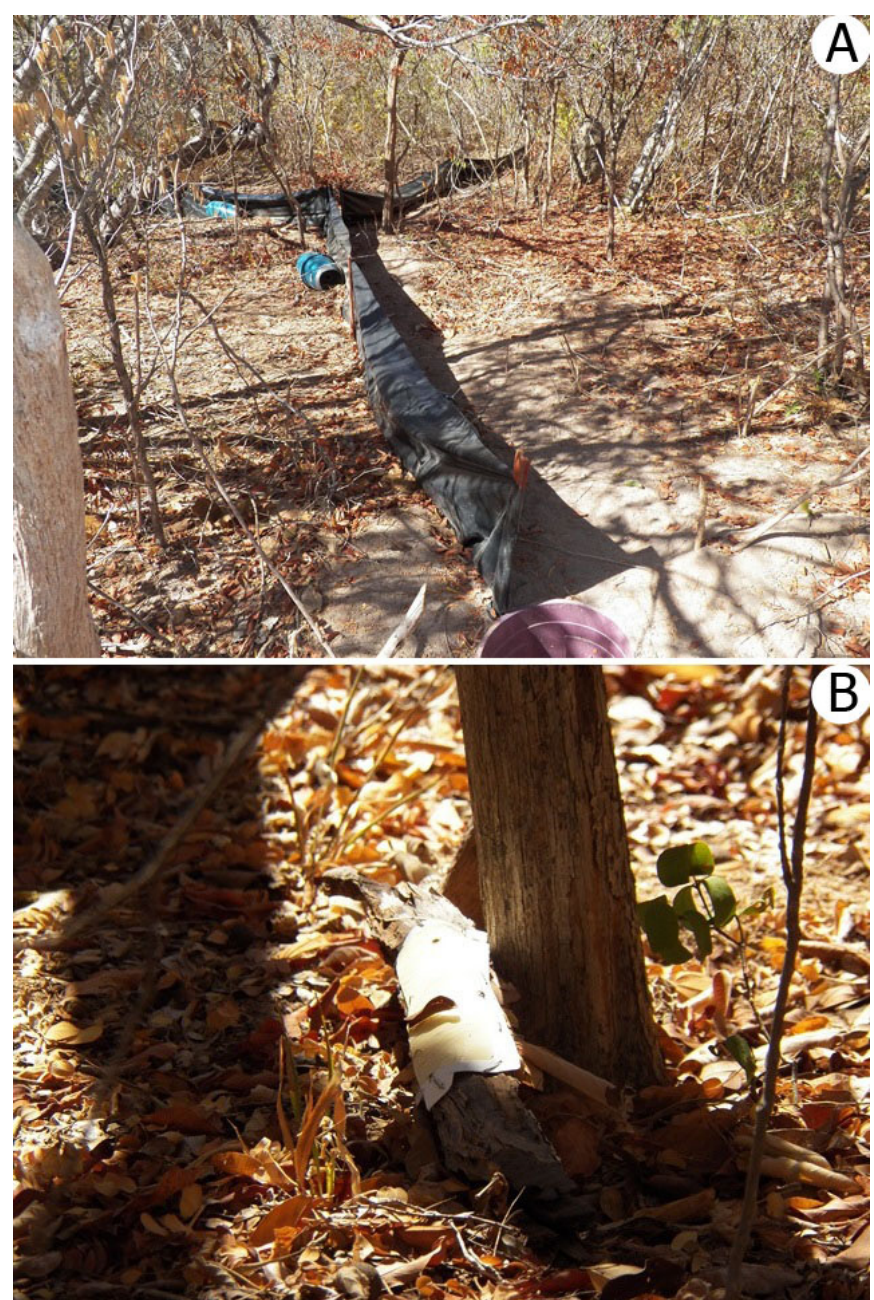

FIGURE 4. The upper picture (A) demonstrates a funnel and pitfall trap array already installed, while the lower picture (B) shows a close view of how glue traps were set.

To evaluate the quality of our sampling effort, we produced rarefaction curves for lizards, amphibians, and all the herpetofauna combined (amphibians, lizards and snakes), based on individuals (Gotelli and Colwell 2001), using EstimateS 8.2.0 (Colwell 1994). The curves were obtained through 1000 resamplings of the original data, with no reposition.

\section{RESULTS}

We collected 17 lizard, 11 snake, one chelonian, one caecilian, and seven frog species (Table 1, Figures 5-11).

None of the three rarefaction curves reached the asymptote (Figure 12). Despite the large sample size and the connection to Chao2 estimator curve, the rarefaction curve for lizard species is still rising. The reason for this ascendance can be a lack of a few species on our survey, as we did not collect at least two lizard species (Calyptommatus sp. and Gymnodactylus geckoides) recorded for this study site based on previous unpublished data. As expected due to climate conditions during our survey, the amphibian species rarefaction curve is still rising and far from Chao 2 estimator curve.

\section{Discussion}

The lizard richness at PARNA Serra da Capivara is relatively high when compared to the majority of studies on other Caatinga sites. Few Caatinga sites have comparable lizard diversity, varying from 14-21 species (Vitt 1995;
Araújo et al. 2005; Gariglio et al. 2010; Moura et al. 2010). Instead, family and genus richness comparisons reveal quite similar results among Caatinga sites. For example, Teiidae, Tropiduridae and Gekkonidae, which exhibit both high diversity and abundance, presented similar patterns (many species shared between areas) among study sites in Caatinga (Vitt 1995; Loebmann and Haddad 2010; Garda et al. 2013). On the contrary, in lizard families such as Gymnophthalmidae, the Caatinga sites contain a similar number of species, but of different taxa.

Perhaps these differences can be related to habitat heterogeneity, such as the presence of forested areas, rocky outcrops, or open, arbustive ones. This endorses the importance of protected areas throughout the Caatinga to protect lizard species. Differences in local microhabitat may be responsible for such species variation among areas (Vitt et al. 2007; Garda et al. 2012), and the extremely small area protected by these reserves is likely not enough to protect all the lizard diversity in the biome. Cnemidophorus venetacaudus was recently described and was known only from Serra das Confusões National Park (Arias et al. 2011). We extend its distribution $100 \mathrm{~km}$ west from the type locality. Two other species reported herein, the gymnophthalmid Procellosaurinus erythrocercus and the tropidurid Stenocercus squarrosus, are reported for few localities in the Caatinga (Ribeiro et al. 2009; Delfim et al. 2011; Freitas and Veríssimo 2012). Furthermore, Colobosaura modesta is commonly found in the Cerrado biome (Colli et al. 2002; Brites et al. 2009), and can also be found in elevated relictual wet forests on Caatinga, known as "Brejos de altitude" (Borges-Nojosa and Caramaschi 2003). Its presence in PARNA Serra da Capivara may be related to some shared floristic and climatic relationships between Serra da Capivara and the Cerrado Biome, as they both share a sandy soil, to which this species is commonly associated, but they also both contain wet forested areas, the "Boqueirões" (Lemos and Rodal 2002).

Because of the shape of our rarefaction curve for amphibians, and supported by our field observations, we believe that climatic conditions in the area were atypical during our fieldwork. Despite collecting only a few amphibian species during the survey, we were still able to obtain some relevant information for a few taxa. One frog species, Leptodactylus aff syphax, was recently collected at Serra de Baturité and Ubajara National Park, both in Ceará State, (Loebmann and Haddad 2010). Furthermore, Siphonops sp. is the first caecilian registered for Piauí State, and one of the few for the Caatinga (Maciel et al. 2013; Miranda et al. 2013). Most of the frogs were found in or near human-made small water reservoirs (locally called "bebedouros"). These reservoirs are used to provide water to birds and mammals that occur in the area, and are refilled with water throughout the dry season. There are over 100 of these "bebedouros" in the area, they provide shelter and may positively affect amphibians in the area.

The severe drought in the region also affected the snake sampling. Snakes are comparatively harder to find and collect than frogs and lizards because of low abundances, secretive habits, and lack of efficient traps, and require longer inventories before a satisfactory result can be achieved (Shine 1991). Nevertheless, we still collected a reasonable portion of the species known 
to occur in Caatinga habitats from Piauí State (Rodrigues and Prudente 2011). The individuals of Thamnodynastes we collected were all from an undescribed species known as Thamnodynastes sp2 (sensu Franco and Ferreira 2002). It is important to highlight that Corallus hortulanus, an arboreal species commonly associated with wetter forested areas, was collected only in the mesic forests in one of the "Boqueirões" (along with several amphibians and the caecilian).

Even with the survey effort made, our sampling is still incomplete. This may be a result of the atypical drought in the region that had been ongoing for almost one year. Furthermore, besides our efforts not being enough to stabilize rarefaction curves for the region we sampled,
PARNA Serra da Capivara is one of the largest protected areas in the Caatinga, and some areas which harbored different vegetation and soil types were logistically difficult to reach. Nevertheless, our study is the first published species list for this study site and one of the few for the Caatinga in Piauí State. We were also able to collect a reasonable portion of lizard diversity in the area. In addition, we provide relevant information on the distribution of some data deficient/rare species of reptiles and amphibians. We suggest that future surveys should be conducted in the wet season and considerable efforts should be directed to other regions (e.g. different soil and vegetation types) in order to achieve a better estimate of the herpetological diversity of PARNA Serra da Capivara.

TABLE 1. List of sampled squamates, chelonians, and amphibians from Parque Nacional Serra da Capirava, Piauí State, Brazil. *Undescribed species previously identified for the area (additional information, Franco and Ferreira 2002).

\begin{tabular}{|c|c|c|c|c|}
\hline & FAMILY & SPECIES & CLAR-UFRN CATALOGUE NUMBER & NUMBER OF SPECIMENS \\
\hline \multicolumn{5}{|c|}{ Lizards } \\
\hline 1 & Gekkonidae & Hemidactylus brasilianus & AAGARDA4724 & 28 \\
\hline 2 & & Lygodactylus klugei & AAGARDA4827 & 14 \\
\hline 3 & Gymnophthalmidae & Colobosaura modesta & AAGARDA4825 & 07 \\
\hline 4 & & Micrablepharus maximiliani & AAGARDA4700 & 100 \\
\hline 5 & & Procellosaurinus erythrocercus & AAGARDA4751 & 92 \\
\hline 6 & Iguanidae & Iguana iguana & AAGARDA4694 & 01 \\
\hline 7 & Leiosauridae & Enyalius bibronii & AAGARDA4792 & 06 \\
\hline 8 & Phyllodactylidae & Phyllopezus pollicaris & AAGARDA4691 & 33 \\
\hline 9 & Scincidae & Mabuya nigropunctata & AAGARDA4837 & 06 \\
\hline 10 & Teiidae & Ameiva ameiva & AAGARDA4785 & 16 \\
\hline 11 & & Cnemidophorus ocellifer & AAGARDA4702 & 36 \\
\hline 12 & & Cnemidophorus venetacaudus & AAGARDA4948 & 20 \\
\hline 13 & & Tupinambis merianae & AAGARDA4799 & 01 \\
\hline 14 & Tropiduridae & Stenocercus squarrosus & AAGARDA4728 & 05 \\
\hline 15 & & Tropidurus heleneae & AAGARDA4686 & 61 \\
\hline 16 & & Tropidurus hispidus & AAGARDA4696 & 100 \\
\hline 17 & & Tropidurus semitaeniatus & AAGARDA4693 & 52 \\
\hline \multicolumn{5}{|c|}{ Chelonians } \\
\hline 1 & Chelidae & Mesoclemmys tuberculata & AAGARDA5019 & 01 \\
\hline \multicolumn{5}{|c|}{ Caecilians } \\
\hline 1 & Caecilidae & Siphonops sp. & AAGARDA5273 & 01 \\
\hline \multicolumn{5}{|c|}{ Anurans } \\
\hline 1 & Bufonidae & Rhinella granulosa & AAGARDA5489 & 03 \\
\hline 2 & & Rhinella jimi & AAGARDA4705 & 06 \\
\hline 3 & Hylidae & Scinax $x$-signatus & AAGARDA4707 & 04 \\
\hline 4 & Leptodactylidae & Leptodactylus aff syphax. & AAGARDA5239 & 05 \\
\hline 5 & & Leptodactylus troglodytes & AAGARDA5263 & 02 \\
\hline 6 & & Leptodactylus vastus & AAGARDA5235 & 05 \\
\hline 7 & & Physalaemus cuvieri & AAGARDA5503 & 01 \\
\hline \multicolumn{5}{|c|}{ Snakes } \\
\hline 1 & Boidae & Corallus hortulanus & AAGARDA5365 & 02 \\
\hline 2 & Colubridae & Oxybelis aeneus & AAGARDA5467 & 02 \\
\hline 3 & & Spilotes pullatus & AAGARDA5367 & 01 \\
\hline 4 & Dipsadidae & Oxyrhopus trigeminus & AAGARDA5270 & 02 \\
\hline 5 & & Philodryas nattereri & AAGARDA4802 & 04 \\
\hline 6 & & Philodryas olfersii & AAGARDA5274 & 01 \\
\hline 7 & & Rodriguesophis iglesiasi & AAGARDA4889 & 01 \\
\hline 8 & & Pseudoboa nigra & AAGARDA4890 & 01 \\
\hline 9 & & Thamnodynastes sp.2 & AAGARDA4886 & 06 \\
\hline 10 & & Xenodon merremi & AAGARDA5364 & 01 \\
\hline 11 & Viperidae & Bothrops lutzi & AAGARDA5468 & 02 \\
\hline
\end{tabular}



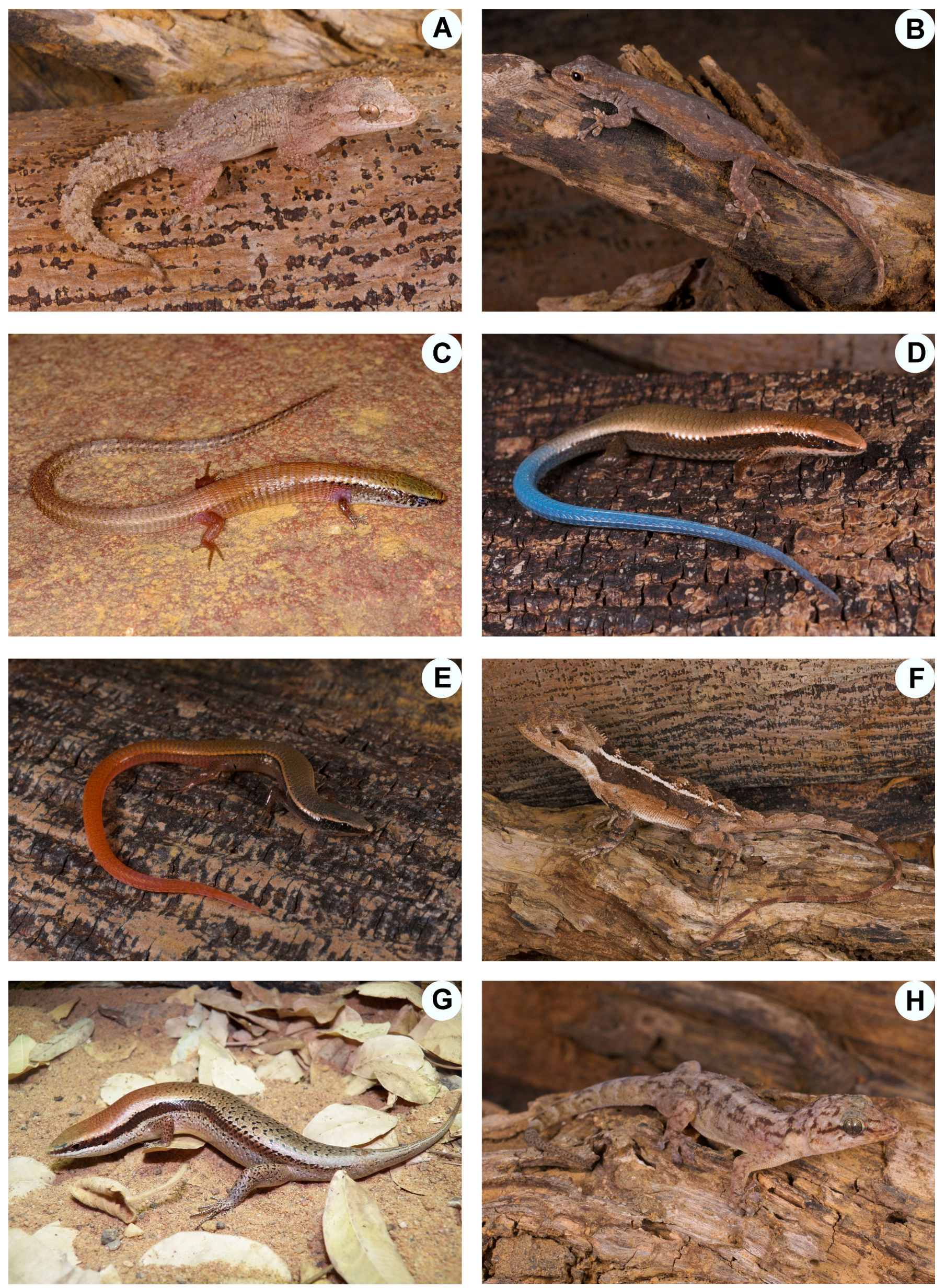

FIGURE 5. Lizards collected at Serra da Capivara - (A) Hemidactylus brasilianus, (B) Lygodactylus klugei, (C) Colobosaura modesta, (D) Micrablepharus maximiliani, (E) Procellosaurinus erythrocercus, (F) Enyalius bibronii, (G) Mabuya nigropunctata, (H) Phyllopezus pollicaris, 

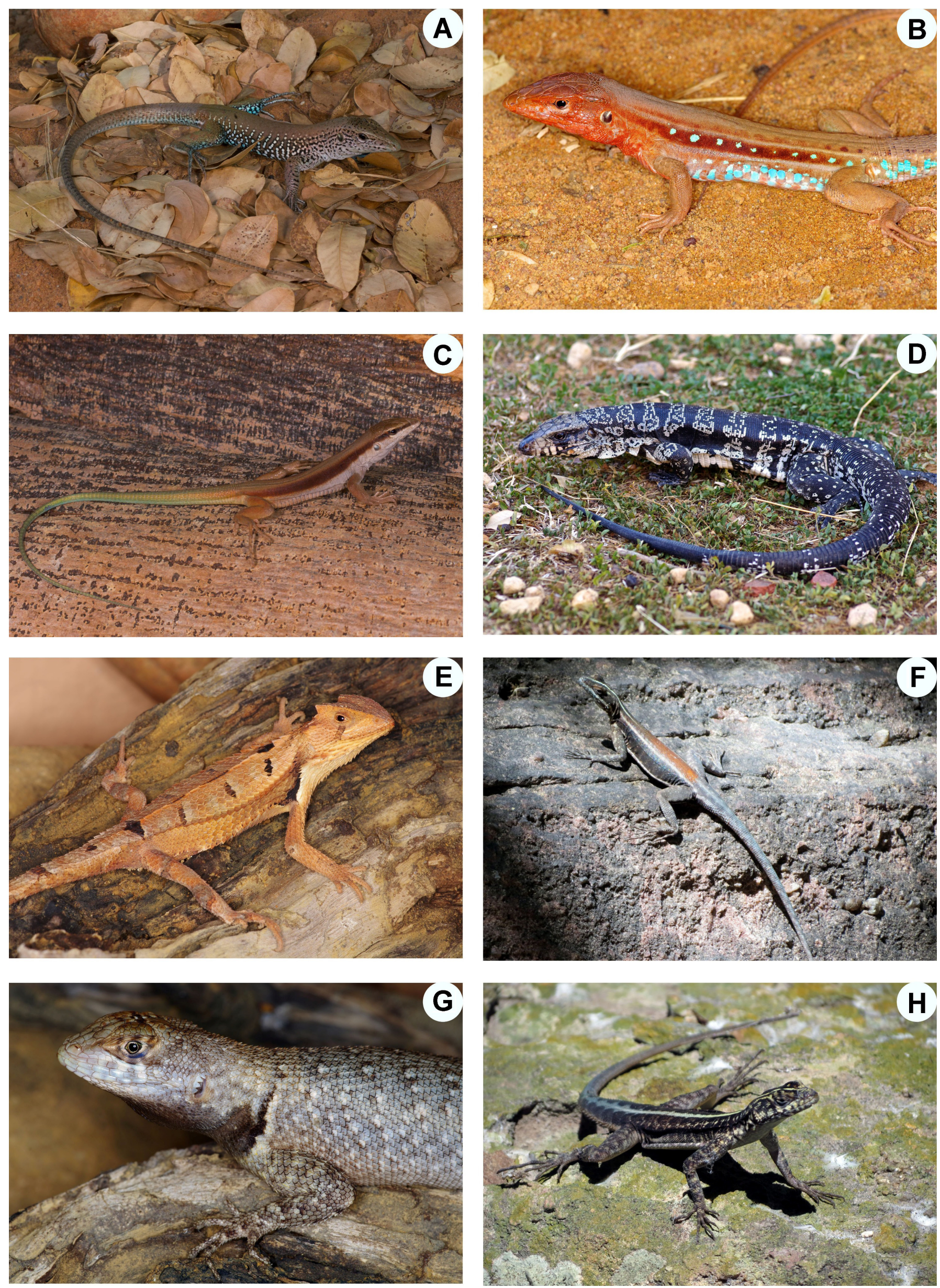

Figure 6. Lizards collected at Serra da Capivara - (A) Ameiva ameiva, (B), Cnemidophorus ocellifer, (C) Cnemidophorus venetacaudus, (D) Tupinambis merianae, (E) Stenocercus squarrosus, (F) Tropidurus helenae, (G) Tropidurus hispidus, (H), Tropidurus semitaeniatus, 

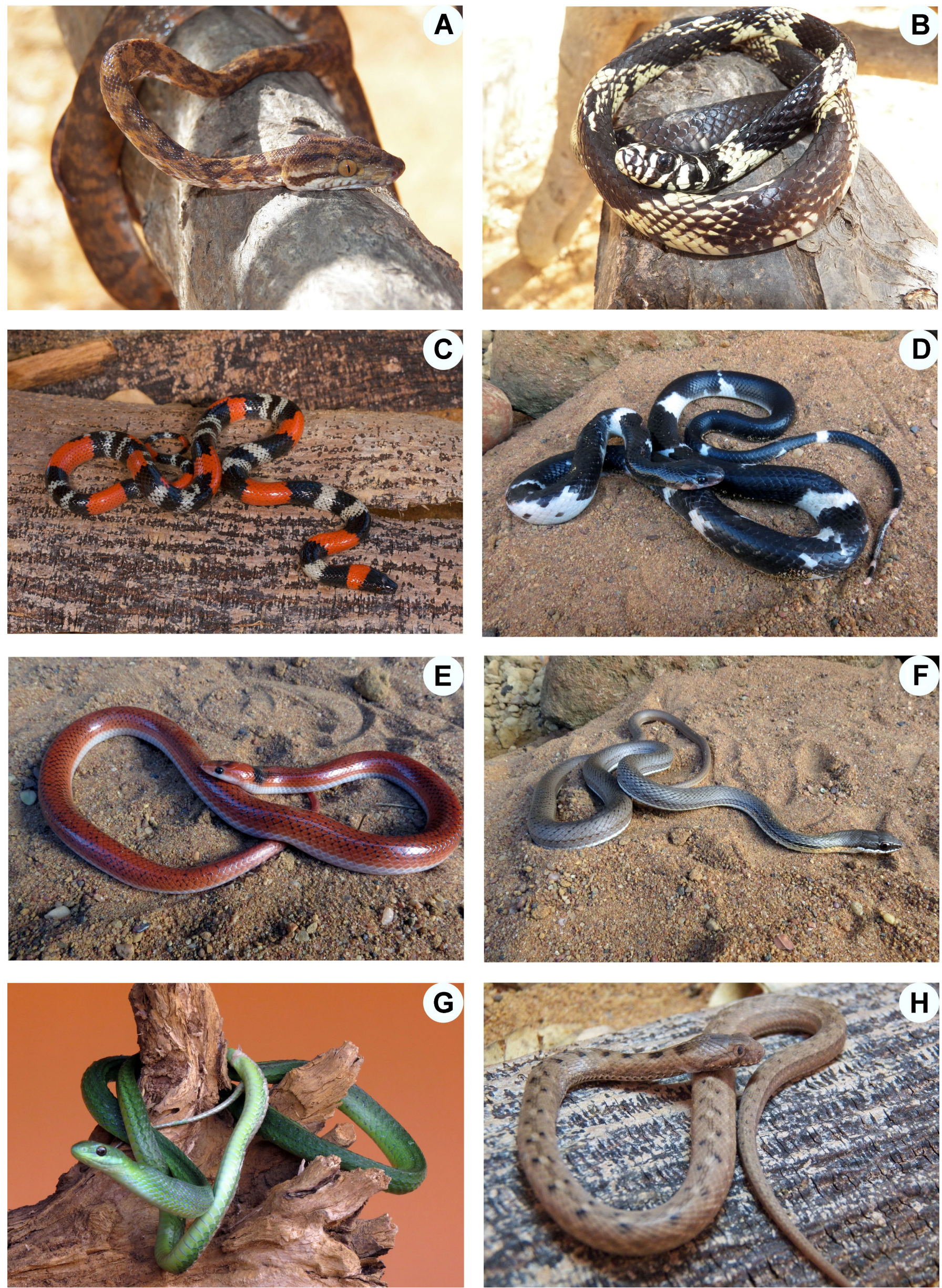

Figure 7. Lizards and snakes collected at Serra da Capivara - (A) Corallus hortulanus, (B) Spillotes pullatus, (C) Oxyrhopus trigeminus, (D) Pseudoboa nigra, (E) Rodriguesophis iglesiasi, (F), Philodryas nattereri, (G) Philodryas olfersii, (H) Thamnodynastes sp2. 

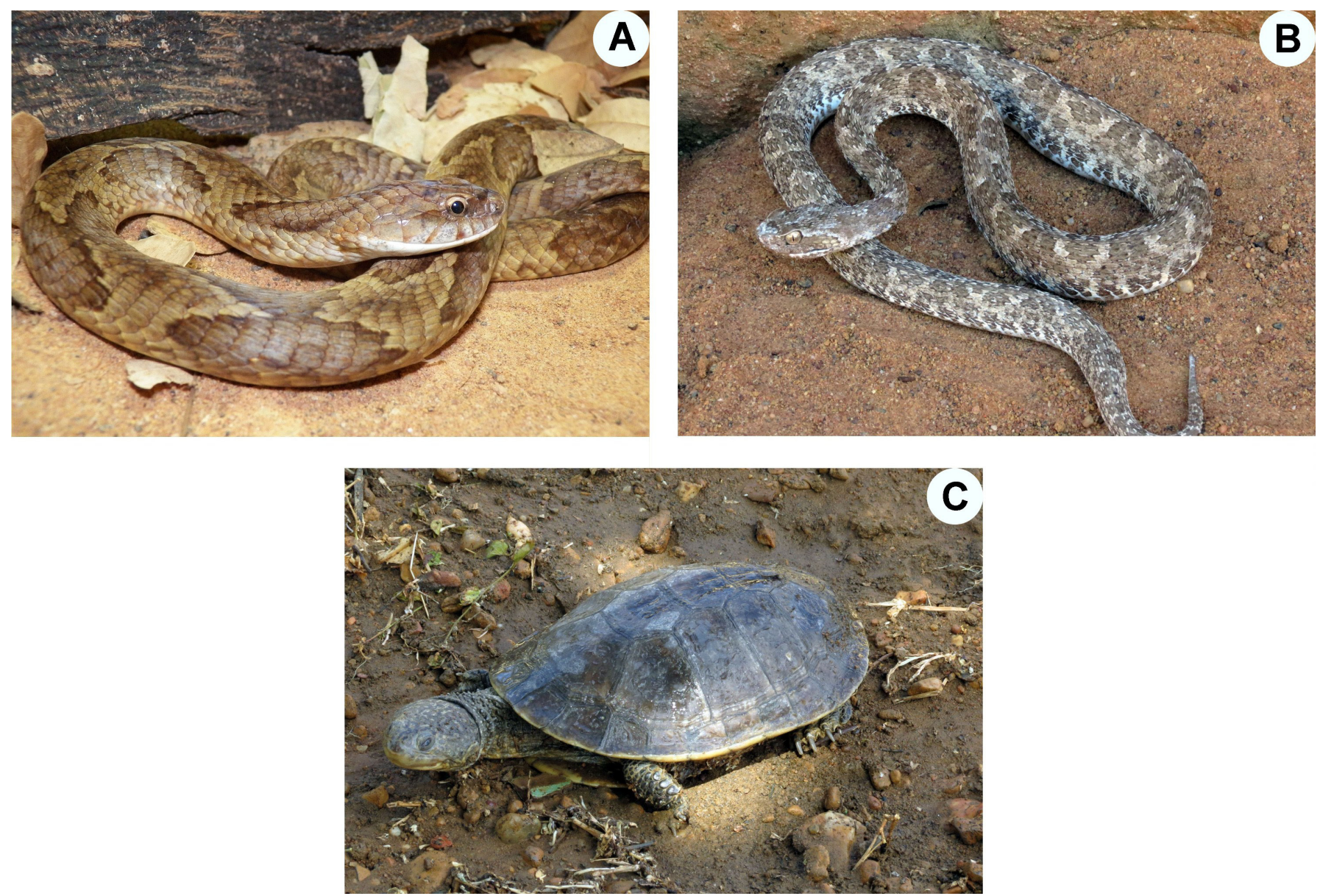

Figure 9. Snakes and turtle collected at Serra da Capivara - (A) Xenodon merremii, (B) Bothrops lutzi, (C) Mesoclemmys tuberculata.
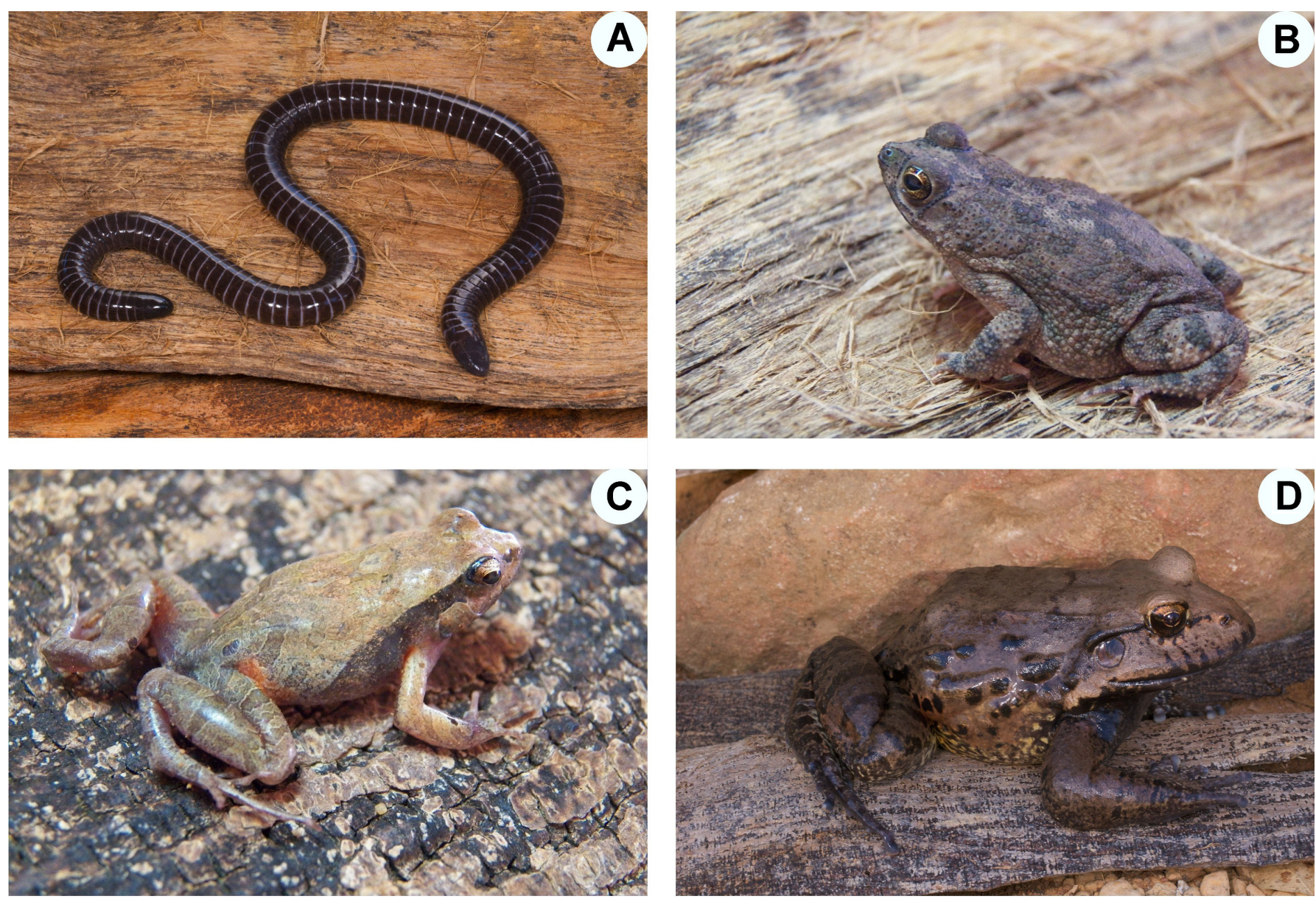

Figure 10. Amphibians collected at Serra da Capivara - (A) Siphonops sp. (B) Rhinella granulosa, (C) Physalaemus cuvieri, (D), Leptodactylus vastus. 

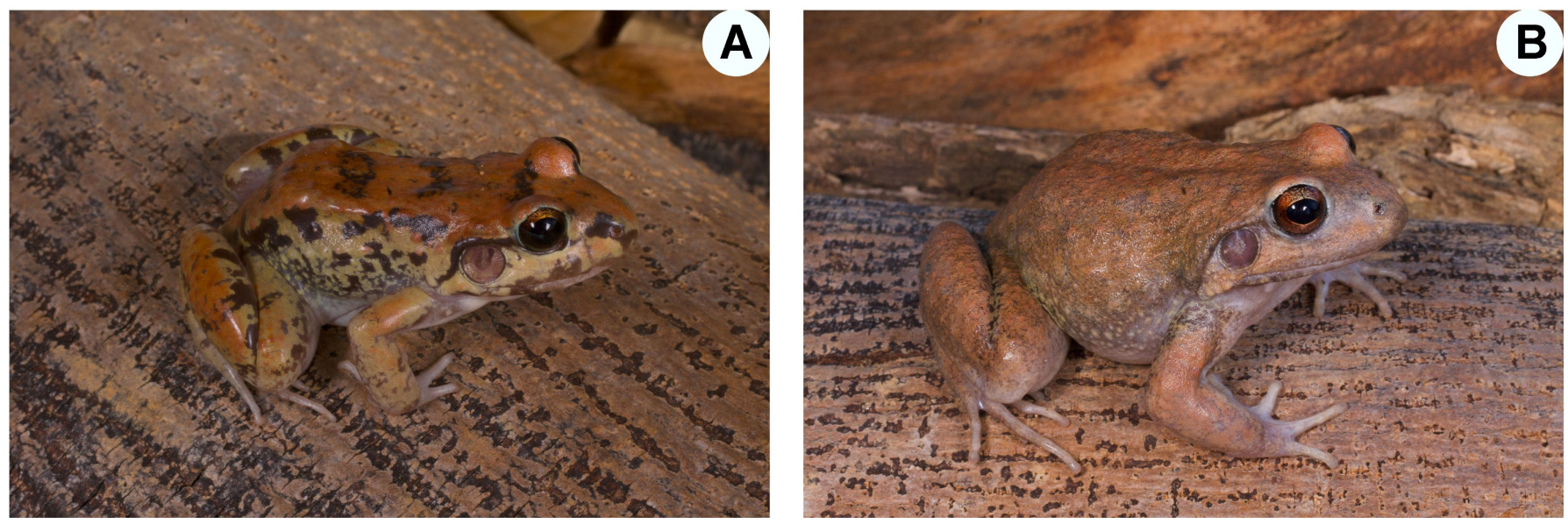

FIGURE 11. Amphibians collected at Serra da Capivara - (A) Leptodactylus troglodytes, (B) Leptodactylus aff. syphax.
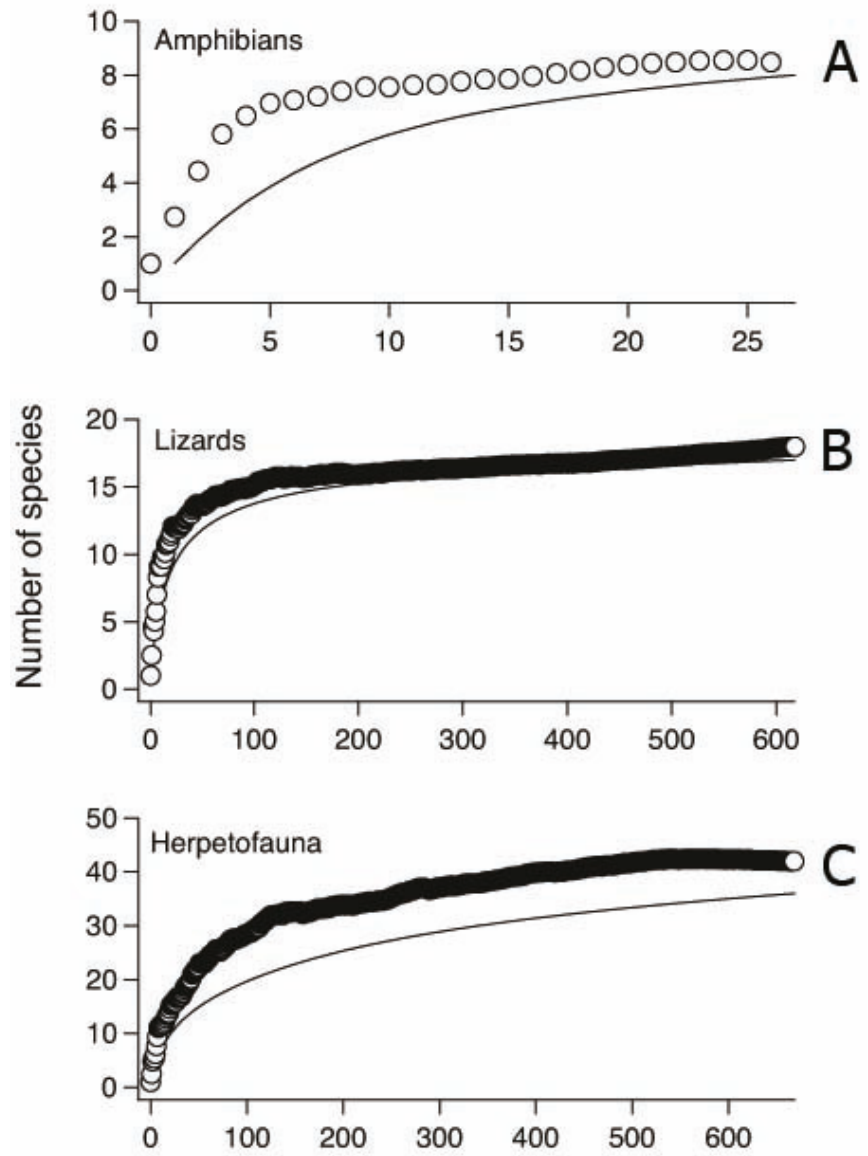

Number of individuals

FIGURE 12. Accumulation and rarefaction curve for amphibians (A), lizards (B) and pooled herpetofauna (C). Narrow black lines represent collected individuals while circles (and broad black lines) are the total species estimates based on Chao2.

ACKNOWLEDGMENTS: We are in debt to all students and guest professors participating in the course Biologia dos Répteis (a joint course offered by UnB, UFPB, and UFRN) for help during fieldwork. We also thank C. R Simões for editing photographs. We are grateful to the crew of "Parque Nacional Serra da Capivara" for logistic and personnel support during our fieldwork. DOM thanks the University of Texas at Austin and Eric Pianka for providing conditions to finalize this manuscript. GCC thanks CNPq grants 302776/2012-5 and 563352/2010-8. This work was fully supported by a grant from $\mathrm{CNPq} / \mathrm{ICMBio}$ to AAG entitled "Representatividade da Herpetofauna em Unidades de Conservação da Caatinga: Diversidade, Filogeografia e Relações com Biomas não Florestais Brasileiros" (Processo \# 552031/2011-9).

\section{Literature Cited}

Araújo, F.S., M.J.N. Rodal and M.R.V. Barbosa. 2005. Análise das Variações da Biodiversidade do Bioma Caatinga: Suporte a estratégias regionais de conservação. Brasília: Ministério do Meio Ambiente. 446 pp.

Arias, F., C.M. Carvalho, M.T. Rodrigues and H. Zaher. 2011. Two new species of Cnemidophorus (Squamata: Teiidae) from the Caatinga, Northwest Brazil. Zootaxa 2787: 37-54.

Borges-Nojosa, D.M. and U. Caramaschi. 2003. Composição e Análise Comparativa da Diversidade e das Afinidades Biogeográficas dos Lagartos e Anfisbenídeos (Squamata) dos Brejos Nordestinos; pp. 489-540, in: I. Leal, Silva, J.M.C. and Tabarelli, M. (ed.) Ecologia e Conservação da Caatinga. Recife: UFPE.

Brites, V.L.C., R.G. Faria, D.O. Mesquita and G.R. Colli. 2009. The herpetofauna of the neotropical savannas; pp. 1-24, in: K. Del Claro (ed.). Encyclopedia of Life Support Systems (EOLSS). Oxford, UK: Eolss Publishers.

Cechin, S.Z. and M. Martins. 2000. Eficiência de armadilhas de queda (pitfall traps) em amostragens de anfíbios e répteis no Brasil. Revista Brasileira de Zoologia 17: 729-740.

Colli, G.R., R.P. Bastos and A.F.B. Araújo. 2002. The character and dynamics of the Cerrado herpetofauna; pp. 223-241, in: P.S. Oliveira and R.J. Marquis. (ed.) The Cerrados of Brazil: Ecology and Natural History of a Neotropical Savanna. New York: Columbia University Press.

Colwell, R.K. (1994). EstimateS: statistical estimation of species richness and shared species from samples. Accessible at http://viceroy.eeb. uconn.edu/estimates.

Corn, P.S. 1994. Straight-line drift fences and pitfall traps; pp. 109-117, in: W.R. Heyer, M.A. Donnely, R.W. McDiarmid, L.-A. Hayek and M. Foster. (ed.) Measuring and monitoring biological diversity: standard methods for amphibians. Washington, D. C.: Smithsonian Institution Press.

Delfim, F.R., D.O. Mesquita, H. Fernandes-Ferreira and L.B.Q. Cavalcanti. 2011. Procellosaurinus erythrocercus Rodrigues, 1991 (Squamata: Gymnophthalmidae): Distribution extension. Check List 7: 856-858.

Franco, F.L. and T.G. Ferreira. 2002. Descrição de uma nova espécie de Thamnodynastes Wagler, 1830 (Serpentes, Colubridae) do nordeste brasileiro, com comentários sobre o gênero. Phyllomedusa 1: 57-74.

Freitas, M.A. and D. Veríssimo. 2012. First record of the lizard Procellosaurinus erythrocercus (Rodrigues, 1991), (Squamata: Gymnophtalmidae) for the Brazilian state of Piauí, Brazil. Herpetology Notes 5: 35-36.

Garda, A.A., T.B. Costa, C.R.S. Silva, D.O. Mesquita, R.G. Faria, B.M. Conceição, I.R.S. Silva, A.S. Ferreira, S.M. Rocha, C.N.S. Palmeira, R. Rodrigues, S.F. Ferrari and S. Torquato. 2013. Herpetofauna of protected areas in the Caatinga I: Raso da Catarina Ecological Station (Bahia, Brazil). Check List 9(2): 405-414.

Garda, A.A., H.C. Wiederhecker, A.M. Gainsbury, G.C. Costa, R.A. Pyron, G.H.C. Vieira, F.P. Werneck and G.R. Colli. 2012. Microhabitat Variation Explains Local-scale Distribution of Terrestrial Amazonian Lizards in Rondônia, Western Brazil. Biotropica 45(2): 245-252.

Gariglio, M.A., E.V.S.B. Sampaio, L.A. Cestaro and P.Y. Kageyama. 2010. Uso sustentável e conservação dos recursos florestais da caatinga. Brasília: Serviço Florestal Brasileiro. 368 pp.

Gotelli, N.J. and R.K. Colwell. 2001. Quantifying biodiversity: procedures and pitfalls in the measurement and comparison of species richness. Ecologiy Letters 4: 379-391.

Leal, I.R., J.M.C. Silva, M. Tabarelli and T.E.L. Jr. 2005. Mudando o curso da conservação da biodiversidade na Caatinga do Nordeste do Brasil. 
Megadiversidade 1: 139-146.

Leal, I.R., M. Tabarelli and J.M.C. Silva. 2003. Ecologia e Conservação da Caatinga. Pernambuco: Editora Universitária UFPE. 804 pp.

Lemos, J.R. 2004. Composição florística do Parque Nacional Serra da Capivara, Piauí, Brasil. Rodriguésia 55: 55-66.

Lemos, J.R. and M.J.N. Rodal. 2002. Fitossociologia do componente lenhoso de um trecho da vegetação de caatinga no Parque Nacional Serra da Capivara, Piauí, Brasil. Acta Botanica Brasilica 16: 23-42.

Loebmann, D. and C.F.B. Haddad. 2010. Amphibians and reptiles from a highly diverse area of the Caatinga domain: composition and conservation implications. Biota Neotropica 10 (3): 227-256.

Maciel, A.O., H.C. Costa, O.G. Drummond, J.O. Gomes and A. D'angiolella. 2013. Rediscovery of Siphonops annulatus (Mikan, 1820) (Amphibia: Gymnophiona: Siphonopidae) in the state of Pará, Brazil, with an updated geographic distribution map, and notes on size and variation. Check List 9: 106-110.

Miranda, J.P., R.F. Matos, F.M. Scarpa and C.F.D. Rocha. 2013. New record and distribution extension of Siphonops paulensis (Gymnophiona: Siphonopidae) in the state of Maranhão, Northeastern Brazil. Herpetology Notes 6: 327-329.

Moura, G.J.B., E.M.X. Freire, E.M. Santos, Z.M.B. Morais, E.A.M. Lins, E.V.E. Andrade and J.D.C. Ferreira. 2010. Distribuição Geográfica e Caracterização Ecológica dos Répteis do Estado de Pernambuco; pp. 277-288, in: G.J.B. Moura, E.M. Santos, M.A.B. Oliveira and M.C.C. Cabral. (ed.) Herpetofauna do Estado de Pernambuco. Brasília: Ministério do Meio Ambiente.

Prado, D.E. 2003. As caatingas da América do Sul; pp. 3-73, in: I.R. Leal, M. Tabarelli and J.M.C. Silva (ed.) Biologia e Conservação da Caatinga. Pernambuco: Editora Universitária UFPE.

Ribeiro, S.C., I.J. Roberto, D.L. Sales and W.O. Almeida. 2009. Distribution extension of Stenocercus squarrosus Nogueira and Rodrigues, 2006
(Reptilia, Squamata, Tropiduridae) in Northeastern Brazil. Biotemas (UFSC) 22: 165-167.

Rodrigues, F.S. and A.L.C. Prudente. 2011. The snake assemblage (Squamata: Serpentes) of a Cerrado-Caatinga transition area in Castelo do Piauí, state of Piauí, Brazil. Zoologia (Curitiba) 28: 440 448.

Rodrigues, M.T. 2003. Herpetofauna da Caatinga; pp. 181-236, in: I.R Leal, M. Tabarelli and J.M.C. Silva (ed.) Biologia e Conservação da Caatinga. Pernambuco: Editora Universitária UFPE.

Shine, R. 1991. Australian Snakes: A Natural History. Ithaca, NY: Cornell University Pressp.

Tabarelli, M. and A. Vicente. 2004. Conhecimento Sobre Plantas Lenhosas da Caatinga: Lacunas Geográficas e Ecológicas; pp. 101-111, in: J.M.C Silva M. Tabarelli, M.T. Fonseca and L.V. Lins (ed.) Biodiversidade da Caatinga: Áreas e Ações Prioritárias Para a Conservação. Brasília: Ministério do Meio Ambiente.

Vitt, L.J. 1995. The ecology of tropical lizards in the Caatinga of northeast Brazil. Occasional Papers of the Oklahoma Museum of Natural History 1: 1-29.

Vitt, L.J., J.P. Caldwell, G.R. Colli, D.O. Mesquita, A.A. Garda and F.G.R. França. 2007. Detecting variation in microhabitat use in low diversity lizard assemblages across small-scale habitat gradients. Journal of Herpetology 41: 653-662.

Werneck, F.P. 2011. The diversification of eastern South American open vegetation biomes: Historical biogeography and perspectives. Quaternary Science Reviews 30: 1630-1648.

RECEIVED: March 2013

ACCEPTED: December 2013

PuBLISHED ONLINE: February 2014

EDITORIAL RESPONSIBILITY: Ross MacCulloch 